\title{
REFERENCES
}

Denton, C. A. \& Kellogg, W. L. (1953). Arch. Biochem. Biophys. 46, 105.

Fischer, N. A., Benson, E. M. \& Swendseid, M. (1958). Arch. Biochem. Biophys. 74, $45^{8}$.

Ford, J. E. (1953). Brit. F. Nutr. 7, 299.

Gregory, M. E. (1954). Brit. F. Nutr. 8, 340.

Lens, J., Wijmenga, H. G., Wolff, R., Karlin, R., Winkler, K. C. \& De Haan, P. G. (1952). Biochim. biophys. Acta, 8, 56.

Mikata, M. (1953). F. agric. chem. Soc. Fapan, 27, 853.

Ostrowski, W. (1955). Acta biochim. polon. 2, 297.

Ostrowski, W., Skarżyński, B. \& Żak, Z. (1954). Acta biochim. polon. I, I3.

Ross, G. I. M. (1952). F. clin. Path. 5, 250.

Seaman, G. R. \& Sanders, F. (1957). Science, 125, 398.

Woodruff, H. B. \& Foster, J. C. (r950). F. biol. Chem. 183, 569.

Woolley, D. W. (1955). Proc. nat. Acad. Sci., Wash., 4I, I I r.

\section{Growth response to dietary penicillin of germ-free chicks and of chicks with a defined intestinal flora}

\author{
By M. LEV (W. K. Kellogg Foundation Fellow)* and M. FORBES† \\ Germ-free Animal Research Unit, Walter Reed Army Institute of Research, \\ Washington, D.C.
}

(Received 29 fuly 1958)

In certain circumstances, antibiotics added to the diet increase the rate of growth of chicks (for review see Jukes, 1955). Coates, Dickinson, Harrison, Kon, Porter, Cummins \& Cuthbertson (1952) and Coates, Davies, Harrison, Kon \& Porter (1955) have suggested that this action of penicillin added to a diet complete in all known essential nutrients may be due to the suppression of an unidentified 'infection' that depresses growth. This view was recently confirmed in a series of experiments with germ-free and conventional chicks (Forbes \& Park, 1958). Lev, Briggs \& Coates (1956, 1957) observed that spores of Clostridium welchii type A were present in the caecums of chicks from the 'infected' premises I day after feeding, but not in those from the clean environment. A growth stimulation by penicillin occurred only in the 'infected' premises where the growth rate of chicks was depressed compared with that of the chicks in the clean quarters. Penicillin in the diet either eliminated the clostridia from the intestines of the chicks or reduced the lecithinase production of these organisms. Thus the presence of $C l$. welchii type A in the caecums of chicks was associated with growth depression, and elimination of the organisms or reduction in their toxigenicity accompanied the reversal by penicillin of the growth depression. Because of the complex nature of the intestinal flora it was not possible by the usual bacteriological techniques to determine the role of clostridia in the growth of chicks. Germ-free chicks, or chicks in which a defined flora had been implanted, seemed to permit a direct approach to the problem.

* On leave from the National Institute for Research in Dairying, Shinfield, Reading, England.

+ Present address: Department of Microbiology, Temple University School of Medicine, Philadelphia, $\mathrm{Pa}$. 
Experiments are reported here on the effect of certain species of bacteria on the growth of chicks free of all other bacteria and fungi and on the growth response of such birds to penicillin supplements in the diet. The strains of bacteria selected for these studies were from those predominant in the intestinal flora, such as Escherichia coli, Lactobacillus lactis, Streptococcus liquefaciens and Cl. welchii type A (Lev \& Briggs, 1956a, $b$; Lev et al. 1957).

\section{EXPERIMENTAL}

\section{Experimental design}

The growth and the growth response to penicillin of germ-free chicks were compared with those of germ-free chicks deliberately implanted with (1) Cl. welchii, (2) Strep. liquefaciens, E. coli and Lb. lactis together, with and without $C l$. welchii.

\section{Chicks}

White Leghorn chicks were used. The germ-free chicks and the chicks with a defined intestinal flora were raised in Reyniers germ-free units (Reyniers, Trexler, Ervin, Wagner, Luckey \& Gordon, 1949). The method for rearing the germ-free chicks was modelled on that of Reyniers et al. (I949), and was that used in previous experiments (Forbes \& Park, 1958).

\section{Diet}

A semi-synthetic casein-starch diet, C-rR (Forbes \& Park, I958), which allowed excellent growth of germ-free and conventional chicks, was used, and its composition is shown in Table I. It was made up and mixed in $20 \mathrm{~kg}$ batches, sterilized and transferred to the germ-free units. For sterilization $\mathrm{I} \mathrm{kg}$ portions were placed in gauze

Table r. Composition of chick diet $C-\mathrm{r} R$ (Forbes $\mathcal{E}^{\circ}$ Park, 1958)

\begin{tabular}{|c|c|c|c|}
\hline Ingredient & $\begin{array}{l}\text { Quantity/ } \\
\text { I00 g }\end{array}$ & Ingredient & $\begin{array}{l}\text { Quantity } \\
\text { I00 g }\end{array}$ \\
\hline Maize starch (g) & $57 \cdot 1$ & Vitamin $\mathrm{B}_{12}$, crystalline* $(\mathrm{mg})$ & 0.005 \\
\hline Casein, purified* $(\mathrm{g})$ & $25^{\circ} 0$ & Vitamin A acetate* (i.u.) & 2600 \\
\hline Maize oil (g) & $5 \cdot 0$ & Vitamin $\mathrm{D}_{3}$, crystalline* (i.u.) & 100 \\
\hline Alphacel* $(g)$ & $3 \cdot 0$ & DL- $\alpha$-tocopherol* $(\mathrm{mg})$ & 5 \\
\hline Glycine $(\mathrm{g})$ & $\mathrm{I} \cdot 5$ & & \\
\hline L-Árginine $\mathrm{HCl}(\mathrm{g})$ & $I \cdot 0$ & $\mathrm{CaCO}_{3}(\mathrm{~g})$ & $2 \cdot 5$ \\
\hline DL-Methionine (g) & 0.5 & $\mathrm{~K}_{2} \mathrm{HPO}_{4}(\mathrm{~g})$ & $1 \cdot 72$ \\
\hline Choline $\mathrm{HCl}(\mathrm{g})$ & 0.27 & $\mathrm{Na}_{2} \mathrm{HPO}_{4}(\mathrm{~g})$ & $1 \cdot 4$ \\
\hline Thiamine $\mathrm{HCl}(\mathrm{g})$ & 0.10 & $\mathrm{NaCl}(\mathrm{g})$ & 0.5 \\
\hline Calcium pantothenate (mg) & Io & $\mathrm{MgSO}_{4} \cdot 7 \mathrm{H}_{2} \mathrm{O}(\mathrm{g})$ & 0.45 \\
\hline Nicotinic acid (mg) & Io & $\mathrm{MnSO}_{4} \cdot \mathrm{H}_{2} \mathrm{O}(\mathrm{mg})$ & $3^{\circ}$ \\
\hline Riboflavin (mg) & 4 & $\mathrm{FeSO}_{4}(\mathrm{mg})$ & 12 \\
\hline Pyridoxine $\mathrm{HCl}(\mathrm{mg})$ & 2 & $\mathrm{CuSO}_{4}(\mathrm{mg})$ & $\mathbf{I}$ \\
\hline Folic acid (mg) & I & $\mathrm{CoCO}_{3}(\mathrm{mg})$ & $\mathbf{I}$ \\
\hline Menaphthone (mg) & 0.8 & $\mathrm{ZnSO}_{4} \cdot 7 \mathrm{H}_{2} \mathrm{O}(\mathrm{mg})$ & $\mathbf{I}$ \\
\hline Biotin (mg) & 0.1 & $\mathrm{KI}(\mathrm{mg})$ & 0.3 \\
\hline
\end{tabular}

* Nutritional Biochemicals Corporation, Cleveland, Ohio, U.S.A.

bags in a layer not exceeding $I$ in. in thickness in the jacketed autoclave of each germfree unit. Steam was allowed to flow through the autoclave for $10 \mathrm{~min}$, the pressure was then increased to $17 \mathrm{lb}$./sq. in. $\left(122^{\circ}\right)$, maintained for $25 \mathrm{~min}$ and gradually returned to normal. Procaine penicillin $\mathrm{G}$ sealed in glass ampoules was sterilized by 
irradiation at $1,800,000$ rep (roentgen equivalent physical), transferred to the units through a germicidal trap and mixed with the sterile diet. Irradiation did not affect the antibacterial activity of the penicillin as determined by the tube-dilution technique with Staphylococcus aureus (strain $\mathrm{H}$ ) as a test organism. Random samples of the supplemented food taken from the food trays were assayed for penicillin content. Penicillin was always found to be present at the expected level.

As in previous experiments (Forbes \& Park, 1958), the chicks were given canned sterilized water (MacDonald-Bernier Co., Boston, Mass.). Food and water were given ad lib. Food for each group of chicks was offered in a covered tray (about 20 in. long and $2 \frac{1}{2}$ in. wide) provided with nine holes $\left(\mathrm{I}_{4}^{\frac{3}{4}} \mathrm{in} . \times 1 \frac{1}{8} \mathrm{in}\right.$.)

\section{Rearing conditions}

After hatching, the chicks in each germ-free unit were subdivided into two groups of seven to ten chicks of approximately equal weight. In each germ-free unit the two groups of chicks were kept in cages about II in. wide, 22 in. long, and $I_{3}$ in. high (made of $\frac{3}{8}$ in. $\times \frac{3}{8}$ in. wire mesh), one group serving as control, the other receiving the diet supplemented with penicillin. The chicks were weighed weekly. The temperature during the hatching of the chicks was $37^{\circ}$; it was gradually reduced to room temperature $\left(24-26^{\circ}\right)$ from the Ist day until the I 4 th day after hatching, and maintained there until the end of the experiment. The lights in the germ-free units were kept on continuously.

\section{Bacteriological procedures}

Sterility tests of the chicks were performed weekly as described previously (Forbes \& Park, 1958). The various organisms used to make up the defined intestinal flora were isolated from the freeze-dried intestinal contents of chicks reared in the 'infected' premises at the National Institute for Research in Dairying, Shinfield, Reading, where a growth response to penicillin supplements in the diet occurred regularly. These organisms were identified by the Department of Bacteriology, Walter Reed Army Institute of Research, Washington, D.C.

A strain of $C l$. welchii type A that produces $\alpha, \theta$ and $\kappa$ toxins isolated from 'infected' chicks (Lev et al. 1957) was used. Heat-sealed ampoules containing freeze-dried spores prepared in Ellner's medium (Ellner, 1956) were transferred into the germ-free units through the germicidal trap. Each chick was given $10^{4}-10^{6}$ freeze-dried spores in $0.5 \mathrm{ml}$. saline, introduced into the crop by means of a short silicone-rubber tube attached to a I ml. syringe. Lb. lactis and Strep. liquefaciens were grown in microinoculum broth (Difco), E. coli in nutrient broth (Difco). Cultures of each of these organisms that had been incubated at $37^{\circ}$ in $200 \mathrm{ml}$. medium for $18-24 \mathrm{~h}$ were centrifuged, and the cells were suspended in enough saline to provide about $0.5 \mathrm{ml}$. of a mixture of the organisms for each experimental chick. The suspensions containing E. coli, Lb. lactis and Strep. liquefaciens were sealed in glass ampoules and introduced into the germ-free units through the germicidal trap. In adjacent tanks, containing chicks from the same hatchings, $0.5 \mathrm{ml}$. of the same bacterial suspension with and without added $\mathrm{Cl}$. welchii spores was administered to the chicks immediately after 
hatching and before feeding. Vent swabs and faecal specimens were taken I day after introduction of the organisms into the chicks, and tested by appropriate procedures to establish the presence of the artificially implanted flora.

At the termination of an experiment, on the 2 Ist day, five chicks in each group were killed, and bacterial counts were made by the method of Miles \& Misra (1938) at three sites in the intestine, the duodenum, ileum and caecum, pooled samples of the contents from each site being used. The samples were collected in sterile screw-top jars, diluted with sterile saline and homogenized with glass beads. Samples were then removed for dry-weight determination. $\mathrm{Cl}$. welchii were counted on meat-extract agar (Difco) to which $5 \%$ of human serum and $10 \%$ of egg-yolk had been added, E. coli on eosinmethylene blue agar (E.M.B.) (Difco), Lb. lactis on lactobacillus-selection medium (Baltimore Biological Laboratory Co.) and Strep. liquefaciens on nutrient agar to which $5 \%$ of blood had been added. All incubations were made at $37^{\circ}$. Egg-yolk agar plates and blood-agar plates were incubated anaerobically in Brewer's jars, lactobacillusselection plates in an atmosphere of $90 \%$ air and $10 \% \mathrm{CO}_{2}$ and E.M.B. plates aerobically.

\section{RESULTS}

The figures in Table 2 show that $C l$. welchii type $\mathrm{A}$ as the sole intestinal flora depressed the growth of chicks on the basal diet compared with that of the germ-free birds. Supplementation of the diet with procaine penicillin $(45 \mathrm{mg} / \mathrm{kg})$ had no effect on the

Table 2. Growth and growth response to dietary procaine penicillin $\mathrm{G}(45 \mathrm{mg} / \mathrm{kg}$ diet) of germ-free chicks and chicks with an intestinal flora composed of Clostridium welchii type A only

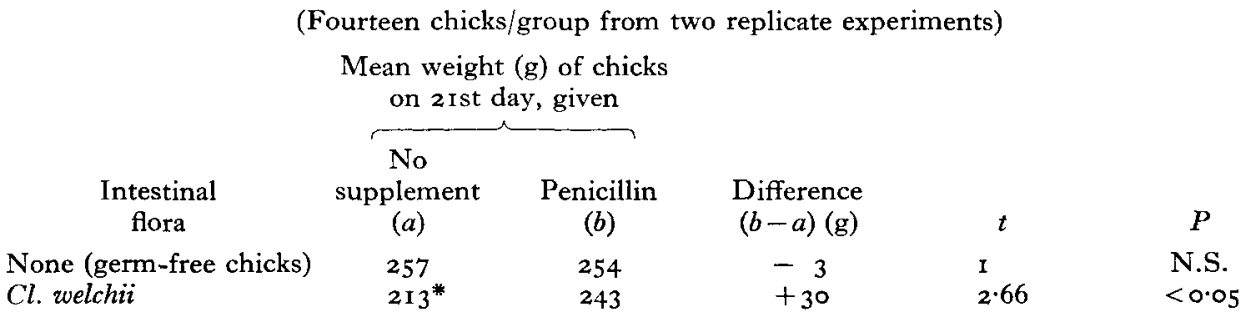

N.S., not significant.

* Significance of difference between germ-free chicks and those with $C l$. welchii: $t=3.69 ; P<0.01$.

growth of germ-free chicks, but counteracted the growth depression in the chicks infected with $\mathrm{Cl}$. welchii only. An intestinal flora composed of $E$. coli, Lb. lactis and Strep. liquefaciens had no effect on the growth rate. However, when besides these three organisms $C l$. welchii was also present, the growth of chicks harbouring them was depressed compared with that of germ-free chicks. Penicillin in the diet had no effect on the growth rate of the chicks with an intestinal flora composed of $E$. coli, Lb. lactis and Strep. liquefaciens, but it did appear to counteract the growth depression when $\mathrm{Cl}$. welchii was present as well (Table 3). The apparent increase in weight was not significant $(P=0 \cdot 1)$, but the results showed a trend similar to that obtained when Cl. welchii was given alone (Table 2). 
The relief by penicillin of the growth depression in the chicks with an intestinal flora composed of $\mathrm{Cl}$. welchii only is explained by bacterial counts on the intestinal content. Penicillin in the diet virtually eliminated $\mathrm{Cl}$. welchii from the intestine (Table 4). In the chicks with a flora composed of E. coli, Lb. lactis, Strep. liquefaciens

Table 3. Growth and growth response to dietary procaine penicillin $G(45 \mathrm{mg} / \mathrm{kg}$ diet) of germ-free chicks and chicks with a defined intestinal flora

(Eighteen to twenty chicks/group from two replicate experiments)

\begin{tabular}{|c|c|c|c|c|c|}
\hline \multirow[b]{2}{*}{$\begin{array}{l}\text { Intestinal } \\
\text { flora }\end{array}$} & \multicolumn{2}{|c|}{$\begin{array}{l}\text { Mean weight }(\mathrm{g}) \text { of chicks } \\
\text { on } 2 \text { Ist day, given }\end{array}$} & \multirow[b]{2}{*}{$\begin{array}{l}\text { Difference } \\
(b-a)(\mathrm{g})\end{array}$} & \multirow[b]{2}{*}{$t$} & \multirow[b]{2}{*}{$P$} \\
\hline & $\begin{array}{c}\text { No } \\
\text { supplement } \\
(a)\end{array}$ & $\begin{array}{l}\text { Penicillin } \\
\quad \text { (b) }\end{array}$ & & & \\
\hline (germ-free chicks) & 240 & $24 I$ & $+\mathbf{I}$ & I & N.S. \\
\hline $\begin{array}{l}\text { species* of } \\
\text { eria }\end{array}$ & 240 & 232 & -8 & $\mathbf{I}$ & N.S. \\
\hline $\begin{array}{l}\text { hree species* } \\
\text { Cl. welchii }\end{array}$ & $213 \dagger$ & 228 & +15 & $1 \cdot 72$ & 0.1 \\
\hline
\end{tabular}

N.S., not significant.

* Escherichia coli, Lactobacillus lactis and Streptococcus liquefaciens.

+ Significance of difference between chicks with three species of bacteria and chicks with the three species and $C l$. welchii: $t=2 \cdot 8 ; P<0 \cdot 01$.

Table 4. Number* of Clostridium welchii $\left(\times 10^{-6} / g\right.$ dry weight $)$ in intestinal contents of chicks, with a flora of $\mathrm{Cl}$. welchii only, fed on the basal diet with and without a supplement of procaine penicillin $\mathrm{G}(45 \mathrm{mg} / \mathrm{kg}$ diet $)$

$\begin{array}{lcc}\text { Intestinal } & \text { No } & \\ \text { segment } & \text { supplement } & \text { Penicillin } \\ \text { Duodenum } & 9.7 & <0.001 \\ \text { Ileum } & 3.7 & <0.001 \\ \text { Caecum } & 2700 & <0.001\end{array}$

* Counts performed on pooled samples of intestinal contents from five chicks.

Table 5. Number* of bacteria $\left(\times 10^{-6} / g\right.$ dry weight $)$ in intestinal contents of chicks with a defined intestinal flora (see p. 79) fed on the basal diet with and without a supplement of procaine penicillin $G(45 \mathrm{mg} / \mathrm{kg}$ diet $)$

\begin{tabular}{|c|c|c|c|c|c|c|c|c|c|}
\hline \multirow{3}{*}{$\begin{array}{c}\text { Exp. } \\
\quad a\end{array}$} & \multirow{2}{*}{$\begin{array}{l}\text { Jritestinal } \\
\text { segment }\end{array}$} & \multicolumn{2}{|c|}{ Cl. welchii } & \multicolumn{2}{|c|}{ E. coli } & \multicolumn{2}{|c|}{ Lb. lactis } & \multicolumn{2}{|c|}{ Strep. liquefaciens } \\
\hline & & U. & P. & U. & P. & U. & $\mathbf{P}$ & $\mathrm{U}$. & P. \\
\hline & Duodenum & 0.029 & $<0.001$ & $4 \cdot 3$ & 3.4 & 87 & $9 \cdot I$ & Not counted & Not counted \\
\hline & Ileum & 0.95 & $<0.001$ & 95 & 1,400 & 100 & 240 & Not counted & Not counted \\
\hline & Caecum & 14 & $<0.001$ & 1,400 & I 1,000 & 470 & $33^{\circ}$ & Not counted & Not counted \\
\hline$b$ & Duodenum & 33 & $2 \cdot 7 \dagger$ & 42 & $8 \cdot 6$ & 28 & 120 & 28 & 240 \\
\hline & Ileum & $2 \cdot 7$ & 9. It & I9 & 37 & 140 & 912 & I 49 & 839 \\
\hline & Caecum & I 5 & $4 \cdot 6 \dagger$ & 25,000 & I 1,000 & 580 & 560 & 8,700 & 6,700 \\
\hline
\end{tabular}

U., unsupplemented; P., procaine penicillin.

* Counts performed on pooled samples of intestinal contents from five chicks.

$\dagger$ These $\mathrm{Cl}$. welchii showed no lecithinase activity on first isolation on the meat-extract-serum-eggyolk plates. Upon subculture they showed as much lecithinase activity as the clostridia from the chicks on the unsupplemented diet. 
and $\mathrm{Cl}$. welchii, the clostridia were fewer than when they were the only bacteria present. Penicillin in the diet of the chicks virtually suppressed the clostridia and had little effect on the three other organisms (Table 5, Exp. a). In one experiment, however, bacterial counts showed that penicillin did not reduce the number of $\mathrm{Cl}$. welchii (Table 5, Exp. $b$ ), but the clostridia did not show their usual characteristic lecithinase activity on egg-yolk agar when first isolated. The colonies of clostridia could readily be counted and recognized, and upon subculture they produced as much lecithinase as those from the chicks on the non-supplemented diet.

Except for a slower rate of weight increase, the chicks infected with $\mathrm{Cl}$. welchii showed no abnormalities in gross appearance during life or at autopsy.

\section{DISCUSSION}

These experiments represent the first attempt to establish in previously germ-free animals a simplified model of the intestinal bacterial flora occurring under natural conditions. The bacterial counts showed that $E$. coli and $L b$. lactis reached numbers similar to those found in normal conventional chicks (Lev \& Briggs, 1956b). Cl. welchii when implanted alone had a predilection for the caecum and, in the presence of $L b$. lactis, Strep. liquefaciens and $E$. coli, were considerably reduced in number. Under certain conditions, not yet defined, penicillin in the diet eliminated the clostridia from the intestine, but under other conditions it reduced their toxigenicity. In either event penicillin in the diet counteracted the growth depression due to the presence of clostridia in the intestine. This reduction of toxigenicity of clostridia seemed to have the same effect on the host as the elimination of the organisms, already shown in conventional chicks (Lev et al. 1957).

The mechanism of the growth-depressing activity of the clostridia on the chicks is not known. Impaired lecithinase production may be only a sign of the effect of penicillin on the organisms. In a preliminary experiment (Forbes, Park \& Lev, 1959) a laboratory strain of Clostridium bifermentans that also produces a lecithinase did not depress growth when established in otherwise germ-free chicks. This species of bacterium is, however, not usually found in the chick intestine.

Our results suggest that $C l$. welchii type $A$ may be a factor in the unidentified 'infection' whose growth-depressing effect is counteracted by penicillin supplements in the diet.

\section{SUMMARY}

I. Germ-free chicks were reared in Reyniers germ-free units and their response to dietary penicillin was compared with that of similar chicks whose gut had been intentionally populated with certain bacteria.

2. Strains of some predominant bacterial species from the intestinal flora of chicks (Escherichia coli, Lactobacillus lactis and Streptococcus liquefaciens) had no effect on growth when implanted together in chicks free of all other bacteria.

3. Clostridium welchii type A, either as sole bacterial species or in the presence of the other three bacteria from the intestinal flora, caused a depression of the growth rate of chicks compared with that of germ-free chicks. 
4. Procaine penicillin $\mathrm{G}$ added to the diet $(45 \mathrm{mg} / \mathrm{kg}$ ) had no effect on the growth of germ-free chicks or of chicks with a flora composed of bacteria that itself did not affect growth, but did counteract the growth depression due to the presence in chicks of $\mathrm{Cl}$. welchii alone or together with a limited defined intestinal flora.

5. Penicillin either eliminated the clostridia from the intestine or reduced their toxigenicity.

6. Cl. welchii may therefore be a factor in the growth-depressing 'infection' that is counteracted by penicillin supplements in the diet.

This investigation was supported in part by the Research and Development Division, Office of the Surgeon General, Department of the U.S. Army, under Contract no. DA-49-007-MD-463. Irradiation of the various samples was performed by $\mathrm{Dr} \mathrm{H}$. Andrews, Radiation Branch, National Cancer Institute (U.S.A.), and Mr J. Hickey, Sanitary Engineering Branch, National Institutes of Health, Bethesda, Md., to whom we are greatly indebted for this service. We gratefully acknowledge the kind assistance of Lieutenant-Colonel H. J. Baker, M.C., and Captain E. Blair of the Department of Bacteriology, Walter Reed Army Institute of Research, Washington, D.C., in typing several bacteria.

\section{REFERENCES}

Coates, M. E., Dickinson, C. D., Harrison, G. F., Kon, S. K., Porter, J. W. G., Cummins, S. H. \& Cuthbertson, W. F. J. (1952). F. Sci. Fd Agric. 3, 43.

Coates, M. E., Davies, M. K., Harrison, G. F., Kon, S. K. \& Porter, J. W. G. (1955). F. Sci. Fd Agric. 6, 4 I 9 .

Ellner, P. D. (1956). F. Bact. 71, 495.

Forbes, M. \& Park, J. T. (1958). F. Nutr. (In the Press.)

Forbes, M., Park, J. 'T. \& Lev, M. (1959). Ann. N.Y. Acad. Sci. (In the Press.)

Jukes, T. H. (1955). Antibiotics in Nutrition. New York, N.Y.: Medical Encyclopedia Inc.

Lev, M. \& Briggs, C. A. E. (1956a). F. appl. Bact. 19, 36.

Lev, M. \& Briggs, C. A. E. (1956b). F. appl. Bact. r9, 224.

Lev, M., Briggs, C. A. E. \& Coates, M. E. (1956). Nature, Lond., 178, I 125.

Lev, M., Briggs, C. A. E. \& Coates, M. E. (1957). Brit. F. Nutr. 11, 364.

Miles, A. A. \& Misra, S. S. (1938). F. Hyg., Camb., 38, 732.

Reyniers, J. A., Trexler, P. C., Ervin, R. F., Wagner, M., Luckey, T. D. \& Gordon, H. A. (1949). In Lobund Reports, no. 2. p. I. [J. A. Reyniers, editor.] Notre Dame, Ind.: University of Notre Dame. 